\title{
Lanthanide Chelates Based on Diethylenetriamine Fitted with $O$-Benzoic Acid Pendant Arms
}

\author{
Daniel Imbert, ${ }^{[a]}$ Nicolas Fatin-Rouge, ${ }^{[a]}$ and Jean-Claude G. Bünzli*[a]
}

Keywords: Carboxylate ligands / Lanthanides / Luminescence / Podand / Stability constant

A new polycarboxylate ligand $\mathrm{H}_{5} \mathrm{~L}$ has been synthesized by the attachment of five benzoate subunits onto a diethylenetriamine framework. Seven $\mathrm{p} K_{a}$ values have been determined by potentiometry, spectrophotometry and NMR spectroscopy as 1.9(2), 2.8(2), 3.87(5), 4.58(6), 4.87(6), 9.19(6) and 11.68(5), the first four corresponding to the carboxylic functions and the last three to amine sites. The interaction between $\mathrm{H}_{5} \mathrm{~L}$ and $\mathrm{Ln}^{\mathrm{III}}$ ions in dilute aqueous solution has been examined by UV/Vis absorption and emission spectrometries, and has been found to result in monometallic complexes that are moderately stable in the $\mathrm{pH}$ range $3.7-7.5$. Conditional stability constants at pH 5.3 are $\log K_{11}=5.3(2), 6.6(1), 6.5(1)$ and 7.2(3) for $\mathrm{La}, \mathrm{Eu}, \mathrm{Tb}$ and $\mathrm{Lu}$, respectively. In the case of $\mathrm{Tb}^{\mathrm{III}}$, the stability constants for $[\mathrm{Tb}(\mathrm{HL})]^{-}$and $\left[\mathrm{Tb}\left(\mathrm{H}_{2} \mathrm{~L}\right)\right]$ are $\log \beta_{111}=22.0(2)$ and $\log \beta_{121}=29.8(1)$, giving a pTb of 10.0 . In the $\mathrm{pH}$ range $4-7$, more than $90 \%$ of the $\mathrm{Tb}^{\mathrm{III}}$ ions are in the form of the neutral species $\left[\mathrm{Tb}\left(\mathrm{H}_{2} \mathrm{~L}\right)\right]$. Lifetime determinations of the $\mathrm{Eu}\left({ }^{5} \mathrm{D}_{0}\right)$ and $\mathrm{Tb}\left({ }^{5} \mathrm{D}_{4}\right)$ excited levels in both $\mathrm{H}_{2} \mathrm{O}$ and $\mathrm{D}_{2} \mathrm{O}$ at $\mathrm{pH} 5.3$ indicate $4.8 \pm 0.5(\mathrm{Eu})$ and $4.5 \pm 0.5$ (Tb) water molecules being bound in the inner coordination sphere of the $\mathrm{Ln}^{\mathrm{III}}$. The triplet state of the ligand in water lies at around $26000 \mathrm{~cm}^{-1}$, resulting in a sizeable sensitisation of the $\mathrm{Tb}$-centred luminescence (absolute quantum yield: $\varphi_{\mathrm{abs}}=$ $10.3 \%$ ), while the luminescence of $\mathrm{Eu}^{\mathrm{III}}$ is only poorly sensitised $\left(\varphi_{\mathrm{abs}}=1.5 \%\right)$.

(ㄷ) Wiley-VCH Verlag GmbH \& Co. KGaA, 69451 Weinheim, Germany, 2003)

\section{Introduction}

Stable chelates of trivalent lanthanide ions are of interest as contrast enhancement agents in magnetic resonance imaging, ${ }^{[1]}$ as catalysts for the cleavage of phosphodiester bonds in DNA and RNA, ${ }^{[2]}$ as precursors for various functional materials, ${ }^{[3]}$ including doped polymers for optical amplifiers, ${ }^{[4]}$ or as luminescent probes for biomedical analysis, ${ }^{[5-7]}$ for responsive analytical sensors ${ }^{[8]}$ or for imaging of cancerous cells. ${ }^{[9]}$ The main difficulty associated with the design of luminescent probes and sensors lies in overcoming the very low molar absorption coefficients of the $\mathrm{Ln}^{\mathrm{III}}$ ions, due to the forbidden nature of the f-f transitions. To sensitise the metal ion efficiently, there are specific requirements for ligand molecules i.e. that they should be strong complexation agents, have large absorption coefficients and offer a series of photophysical properties allowing efficient energy transfer from the ligand onto the metal ion and minimization of quenching processes. ${ }^{[5]}$

Several synthetic strategies intended to meet all these requirements have been examined, ${ }^{[3]}$ including the use of pre-

[a] Swiss Federal Institute of Technology Lausanne, Institute of Molecular and Biological Chemistry

1015 Lausanne, Switzerland

Fax: (internat.) +41-21/693-9825

E-mail: jean-claude.bunzli@epfl.ch

Supporting information for this article is available on the WWW under http://www.eurjic.org or from the author. organised (macrocyclic) ${ }^{[10]}$ or predisposed receptors, ${ }^{[11,12]}$ leading to induced cavities; these receptors can also be obtained by self-assembly processe ${ }^{[13]}$ or by the use of flexible podands. ${ }^{[14]}$ These latter are readily available, cheap and are easy to derivatize. In this paper we attempt to combine the stability of $\mathrm{Ln}^{\mathrm{III}}$ complexes with ligands derived from polyaminocarboxylates, such as $\mathrm{dtpa},{ }^{[15]}$ with the large
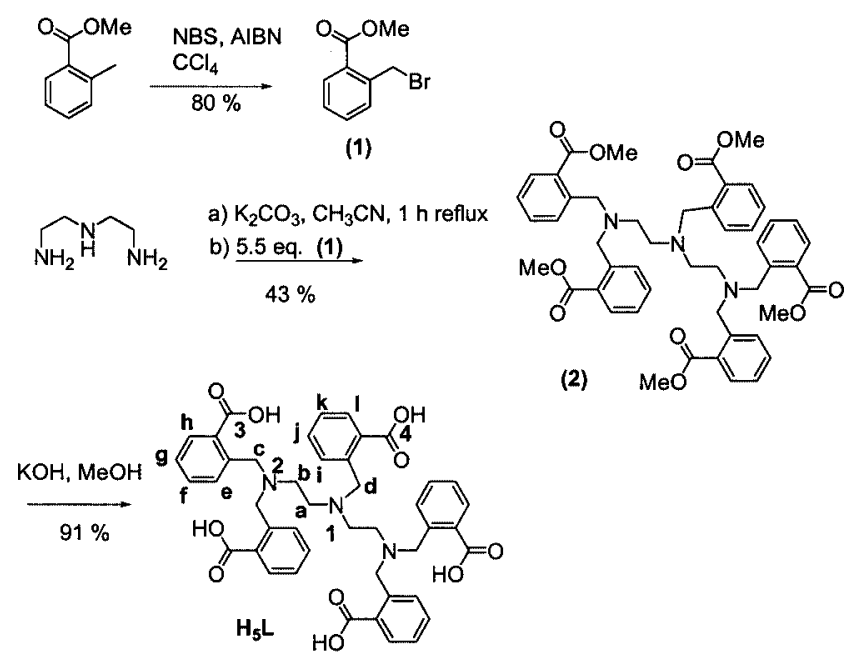

Scheme 1 
sensitisation of $\mathrm{Tb}^{\mathrm{III}}$ ion luminescence (and also other $\mathrm{Ln}^{\mathrm{III}}$ ions) achieved by incorporation of the benzoate chromophore, ${ }^{[5,16]}$ absolute quantum yields of 100 and $20 \%$ having been reported for $\mathrm{Tb}^{\mathrm{III}}$ and $\mathrm{Eu}^{\mathrm{III}}$, respectively, in the solid state. ${ }^{[17]}$ We have therefore synthesized the polydentate ligand $\mathrm{H}_{5} \mathrm{~L}\left[1,4,7\right.$-heptanetriamine- $N, N, N^{\prime}, N^{\prime}, N^{\prime \prime}$-pentakis(2-methylbenzoic acid), Scheme 1] and investigated its complexation and sensitisation properties towards trivalent lanthanide ions.

\section{Results and Discussion}

\section{Acidity Constants of the Ligand}

The ligand $\mathrm{H}_{5} \mathrm{~L}$ was prepared in three steps (Scheme 1) in an overall yield of $31 \%$. Its acidity constants were determined separately by potentiometry (Figure 1) and spectrophotometry (Figure 2) and further confirmed by ${ }^{1} \mathrm{H}$ NMR spectroscopy. The extracted $\mathrm{p} K_{a}$ values, defined by the following equations and obtained by titration in the $2-12 \mathrm{pH}$ range, are summarized in Table 1.

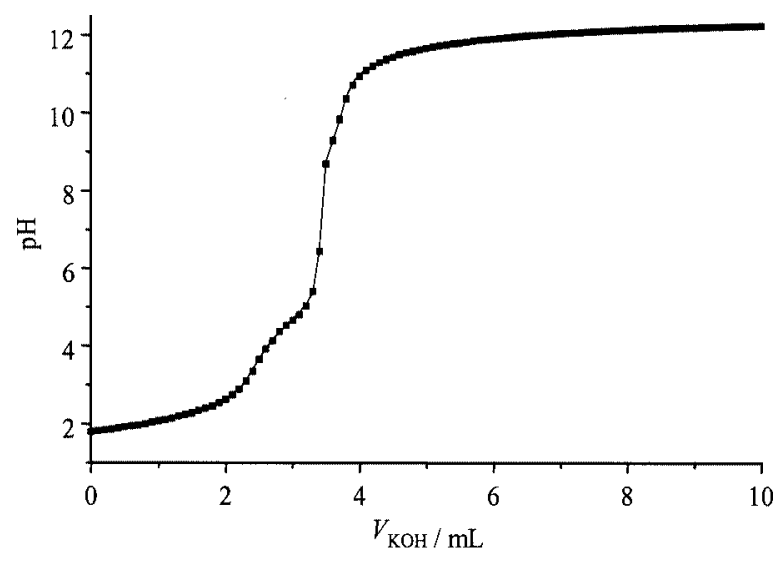

Figure 1. Potentiometric titration of $\mathrm{H}_{7} \mathrm{~L}^{2+}$ with $\mathrm{OH}^{-}$in $\mathrm{H}_{2} \mathrm{O}$ / $\mathrm{CH}_{3} \mathrm{OH}(98: 2 \mathrm{v} / \mathrm{v}) ; T=20.0 \pm 0.2{ }^{\circ} \mathrm{C} ; \mu=0.1 \mathrm{M}(\mathrm{KCl})$

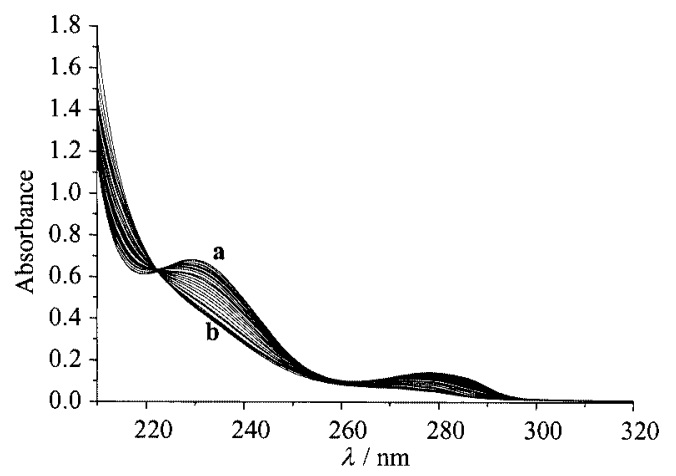

Figure 2. UV/Visible absorption spectra of $\mathrm{H}_{7} \mathrm{~L}^{2+}$ as a function of $\mathrm{pH}$ in $\mathrm{H}_{2} \mathrm{O} / \mathrm{CH}_{3} \mathrm{OH}(98: 2 \mathrm{v} / \mathrm{v}) ; T=20.0 \pm 0.2{ }^{\circ} \mathrm{C} ; \mu=1 \mathrm{~m}(\mathrm{KCl})$ : curve a $(\mathrm{pH}=1.37)$, curve $\mathrm{b}(\mathrm{pH}=12.04)$
Table 1. Acidity constants of $\mathrm{H}_{7} \mathrm{~L}^{2+}( \pm \sigma)$ and dtpa (see text for the definition of $K_{a \mathrm{i}}$ )

\begin{tabular}{llccr}
\hline & $\mathrm{L}^{[\mathrm{a}]}$ & $\mathrm{L}^{[\mathrm{b}]}$ & $\mathrm{L}^{[\mathrm{c}]}$ & $\mathrm{dtpa}^{[\mathrm{d}]}$ \\
\hline $\mathrm{p} K_{a 1}$ & - & $1.9(2)$ & $1.7(4)$ & 1.45 \\
$\mathrm{p} K_{a 2}$ & - & $2.8(2)$ & $2.9(3)$ & 1.75 \\
$\mathrm{p} K_{a 1}+\mathrm{p} K_{a 2}$ & $4.20(8)$ & $4.7(4)$ & $4.6(7)$ & 3.20 \\
$\mathrm{p} K_{a 3}$ & $3.87(5)$ & - & - & 2.06 \\
$\mathrm{p} K_{a 4}$ & $4.58(6)$ & $4.5(2)$ & $4.7(1)$ & 2.73 \\
$\mathrm{p} K_{a 5}$ & $4.87(6)$ & - & - & 4.28 \\
$\mathrm{p} K_{a 6}$ & $9.19(6)$ & $9.4(3)$ & $9.0(4)$ & 8.65 \\
$\mathrm{p} K_{a 7}$ & $11.68(5)$ & $11.6(3)$ & $11.6(4)$ & 10.59 \\
\hline
\end{tabular}

[a] Potentiometric data. $[\mathrm{L}]_{0}=1.0 \cdot 10^{-3} \mathrm{M} ; I=0.1 \mathrm{M}(\mathrm{KCl}) ; T=$ $20.0^{\circ} \mathrm{C}$. ${ }^{[\mathrm{b}]}$ Spectrophotometric data. $[\mathrm{L}]_{0}=2.0 \cdot 10^{-5} \mathrm{M} ; I=1 \mathrm{M}$ $(\mathrm{KCl}) ; T=20.0^{\circ} \mathrm{C}$. ${ }^{\mathrm{cc}]}{ }^{1} \mathrm{H}$ NMR spectroscopic data. $[\mathrm{L}]_{0}=1.0 \cdot 10^{-3}$ M; $T=20^{\circ} \mathrm{C}$. ${ }^{[\mathrm{d}] ~}{ }^{1} \mathrm{H}$ NMR spectroscopic data. $I=0.1 \mathrm{M}\left(\mathrm{KNO}_{3}\right)$; $T=25.0{ }^{\circ} \mathrm{C} \cdot\left[{ }^{[34]}\right.$

$$
\begin{aligned}
&\left(\mathrm{H}_{8-i} \mathrm{~L}\right)^{(3-i)+} \rightleftarrows\left(\mathrm{H}_{7-i} \mathrm{~L}\right)^{(2-i)+}+\mathrm{H}^{+} \\
& \mathrm{p} K_{a i}(i=0-4, \text { carboxylic functions })
\end{aligned}
$$

$\left(\mathrm{H}_{8-i} \mathrm{~L}\right)^{(3-i)+} \rightleftarrows\left(\mathrm{H}_{7-i} \mathrm{~L}\right)^{(2-i)+}+\mathrm{H}^{+}$

$$
\mathrm{p} K_{a i}(i=5-7, \text { amine functions })
$$

The agreement between the values from various experimental techniques is quite good, and the dissociation constants display behaviour similar to that reported for dtpa: five $\mathrm{p} K_{a}$ values are in the 2 to 5 range while the last two are between 9 and 12. A fit of the data with eight $\mathrm{p} K_{a}$ values did not converge, indicating that $\mathrm{p} K_{a 0}$, corresponding to the deprotonation of a carboxylic group (see below, NMR spectra), probably lies below $\mathrm{pH} 2$. However, the protolytic groups of $\mathrm{H}_{5} \mathrm{~L}$ are less acidic than those of dtpa. The first is only slightly less acidic $\left(\Delta \log K_{a}=0.35\right)$, but the difference increases up to $\Delta \log K_{a}=1.9$ for $\mathrm{p} K_{a 4}$. The electron-donor ability of the benzene moieties and the larger number of bonds separating the nitrogen atoms from the carboxylate groups explain this trend.

${ }^{1} \mathrm{H}$ NMR spectra were measured from $\mathrm{pH} 12.2$ to 1.1 in $\mathrm{D}_{2} \mathrm{O} / \mathrm{CD}_{3} \mathrm{OD}$ (95:5) solutions (Figure 3), and the resonances were attributed on the basis of their chemical shifts, signal intensities and ${ }^{1} \mathrm{H}-{ }^{1} \mathrm{H}$ COSY experiments. In the aromatic region, because of superimposed signals, only the protons labelled (i) and (h) could be unambiguously assigned. The eight protons labelled (c) and the two protons labelled (d) appear to be equivalent, pointing to an averaged structure of the molecule on the NMR timescale. The (a) and (b) protons are nonequivalent and appear as two broad peaks because of spin coupling and conformational motions.

The variation of the chemical shifts with $\mathrm{pH}$ is shown at the bottom of Figure 3. At pH 12.2, corresponding to a solution containing mainly the totally deprotonated ligand $\mathrm{L}^{5-}$, the resonances for the (c) and (d) protons have very similar chemical shifts, and this is also true for protons (a) and (b). A decrease in the $\mathrm{pH}$ to 10.4 by the addition of one equivalent of acid causes only slight variations in the 

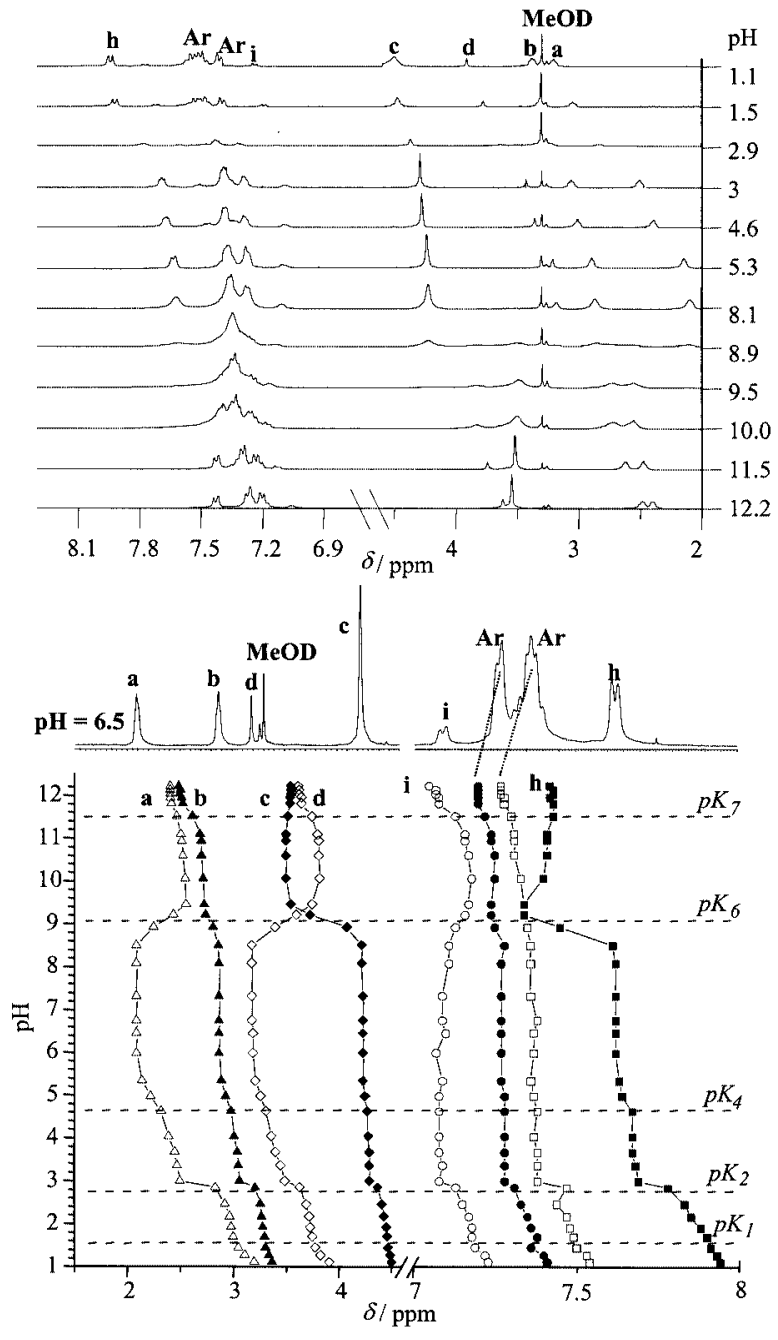

Figure 3. (Top) ${ }^{1} \mathrm{H}$ NMR spectra of $\mathrm{H}_{n} \mathrm{~L}^{(5-n)-}$ vs. $\mathrm{pH}$ in $\mathrm{D}_{2} \mathrm{O} /$ $\mathrm{CD}_{3} \mathrm{OD}(95: 5 \mathrm{v} / \mathrm{v})$ at $T=20^{\circ} \mathrm{C}$, and (bottom) variation of the ${ }^{1} \mathrm{H}$ NMR chemical shifts vs. $\mathrm{pH}$

shifts of the methylene protons, which become more shielded, except for protons (d), which become deshielded. Similarly, the aromatic protons undergo small positive shifts, except for protons (h), which become deshielded. Further addition of acid again results in relatively small changes until around $\mathrm{pH} 9$, except that the shift tendency inverts for protons (d) and (i), which become more shielded. In the $\mathrm{pH}$ range 9 to 3 , dramatic changes occur for the methylene protons and for protons (h); in particular, the resonances of protons (a) and (b) on one hand and (c) and (d) on the other become clearly separated. After a discontinuity at $\mathrm{pH} \mathrm{3,} \mathrm{all} \mathrm{the} \mathrm{protons,} \mathrm{particularly} \mathrm{protons} \mathrm{(h),}$ become more shielded upon further addition of acid.

The observed shift of the methylene protons is in fact an average value reflecting the mean time that each proton spends in a given chemical environment. ${ }^{[18]}$ Quantitative analysis of the $\mathrm{pH}$ dependence of these chemical shifts can therefore be performed by assuming that the contributions to the shift of a given proton $i\left(\delta_{i}\right)$ are additive and linearly related to the fraction of time spent in each environment.
As a result, the preferred protonation sites and the extent of protonation can be estimated from a simple model taking into account only the two closest protonation sites, where $f$ is the fractional population of a given protonation site, $C$ is the chemical shift increment caused by the presence of the proton in this site, and the indices $\alpha$ and $\beta$ refer to the position of the protonated nitrogen atom relative to the resonant proton.

$\delta_{a}=\delta_{\mathrm{a}}^{0}+f_{1} \times C_{\mathrm{N} \alpha}+f_{2} \times C_{\mathrm{N} \beta}$
$\delta_{b}=\delta_{\mathrm{b}}^{0}+f_{2} \times C_{\mathrm{N} \alpha}+f_{1} \times C_{\mathrm{N} \beta}$
$\delta_{c}=\delta_{\mathrm{c}}^{0}+f_{2} \times C_{\mathrm{N} \alpha}+f_{3} \times C_{\mathrm{O} 3}$
$\delta_{d}=\delta_{\mathrm{d}}^{0}+f_{1} \times C_{\mathrm{N} \alpha}+f_{4} \times C_{\mathrm{O} 4}$

We have set $C_{\mathrm{O} 3}, C_{\mathrm{O} 4}, C_{\mathrm{O}}$ to be equal. The $\delta_{\mathrm{i}}^{0}$ values were taken as equal to the chemical shifts measured at $\mathrm{pH}$ 12.2. Finally, the $f_{i}$ values were normalised by the following relationship, where $n$ is the number of equivalents of acid added to the fully deprotonated ligand $\mathrm{L}^{5-}$.

$f_{1}+2 f_{2}+4 f_{3}+f_{4}=n$

Values of $f_{1}, f_{2}$ and $C_{\mathrm{N} \alpha}, C_{\mathrm{N} \beta}$ were obtained only for $n=$ 1 and 2, because the data become too imprecise beyond this amount of acid. For $n=0-2, f_{3}$ and $f_{4}$ were set as equal to zero, which is a reasonable assumption. The best results for $n=1$ were obtained at $\mathrm{pH} 1 / 2\left(\mathrm{p} K_{a 6}+\mathrm{p} K_{a 7}\right)$, and Equations (3), (4), (6) and (7) give $f_{1}=0.22, f_{2}=0.39, C_{\mathrm{N} \alpha}=$ $0.59 \mathrm{ppm}$ and $C_{\mathrm{N} \beta}=0.05 \mathrm{ppm}$. Generally speaking, the $C$ values have large error margins because of the fairly small chemical shift changes. The calculated $C_{N \alpha}$ value is in good agreement with literature data for dtpa (0.75), but the value found for $C_{N \beta}$ is much lower than the reported value of about $0.35 \mathrm{ppm} .{ }^{[18]}$ At $\mathrm{pH} 1 / 2\left(\mathrm{p} K_{a 4}+\mathrm{p} K_{a 3}\right)$, different values of $n$ were again tested and $n=2$ gave the best result, with Equations (3) $-(5)$ and Equation (7) yielding $f_{1}=0.38$, $f_{2}=0.81, C_{N \alpha}=0.82 \mathrm{ppm}$, and $C_{N \beta}=0.77 \mathrm{ppm}$. These calculations offer evidence of the drastic change in the charge repartition on the three nitrogen atoms on going from $n=1$ to $n=2$, consistent with the data for dtpa. ${ }^{[18]}$ At $n=2$, for instance, the protons are mainly bound to the end nitrogen atoms $\mathrm{N} 2$, as a result of electrostatic repulsion. Further attempts to determine quantitatively the extent of protonation of the benzoate groups with $\mathrm{pH}$ failed. Nevertheless, the similar values of the three largest $\mathrm{p} K_{a}$ values for dtpa and for $\mathrm{H}_{5} \mathrm{~L}$ point to the protonation of $\mathrm{L}^{5-}$ occurring first on the three nitrogen atoms. However, distribution diagrams show that protonation of the benzoate sites starts while full protonation of the central nitrogen atom is not yet complete.

\section{Interaction with Trivalent Lanthanide Ions}

The interaction between $\mathrm{Ln}^{\mathrm{III}}$ ions $(\mathrm{Ln}=\mathrm{La}, \mathrm{Eu}, \mathrm{Tb}$, $\mathrm{Lu}$ ) and $\mathrm{H}_{5} \mathrm{~L}$ was first monitored in dilute aqueous solu- 
tions by UV/Vis spectrophotometry at $\mathrm{pH}$ 5.3. The variation of the absorbance versus $R=\left[\mathrm{Ln}^{\mathrm{III}}\right]_{\mathrm{tot}} /\left[\mathrm{H}_{5} \mathrm{~L}\right]_{\mathrm{tot}}($ Figure 3 ) points to the presence of a single 1:1 complex species in the stoichiometry range investigated $(0<R<5)$. This is in agreement with the ESI-MS spectra. The conditional stability constants extracted from these data amount to $\log K_{11}=5.3(2), 6.6(1), 6.5(1)$ and 7.2(3), respectively (Figure S1, Supporting Information, see also the footnote on the first page of this article). The linear relationship between the magnitude of the binding constants and the charge density of the cation is a clear indication that there is no steric effect in the coordination of the metal ions. To determine the influence of the $\mathrm{pH}$ on the speciation, we titrated the ligand in the presence of one equivalent of $\mathrm{Tb}^{\mathrm{III}}$ and monitored the experiment both by spectrophotometry (Figure 4) and by luminescence spectroscopy (Figure 5). Potentiometry could not be used because of precipitation of the metal complexes at concentrations greater than $10^{-3} \mathrm{M}$. The best model used to fit the titration data was fairly complex, with ten different $\left[\operatorname{Ln}_{i}(\mathrm{OH})_{j} \mathrm{H}_{k} \mathrm{~L}_{1}\right]^{(3 i-j+k-5 l)+}$ species: one hydroxide moiety $(i=1 ; j=3 ; k=l=0)$, six protonated forms of the ligand $(i=j=0)$ determined independently from the potentiometric titration described above, and two protonated 1:1 complexes $(i=1, j=0, k=$ 1 and $2, l=1)$. The absorption maxima of the different species are given in Table 2. The two proton-dependent stability constants refined amount to $\log \beta_{111}=22.0(2)$ [Equation (8)] and $\log \beta_{121}=29.8(1)$ [Equation (9)].

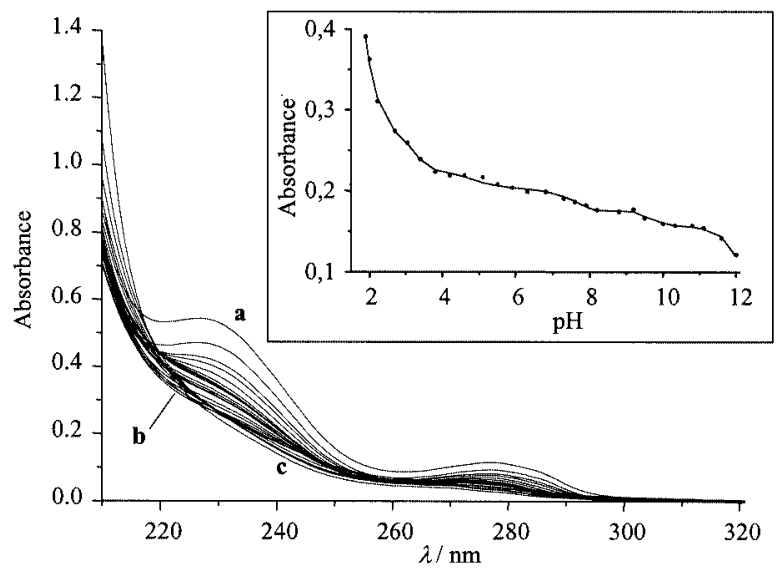

Figure 4. UV/Visible absorption spectra of $\mathrm{H}_{7} \mathrm{~L}^{2+} 2 \cdot 10^{-5} \mathrm{M}$ in $\mathrm{H}_{2} \mathrm{O}$ / $\mathrm{CH}_{3} \mathrm{OH}(98: 2 \mathrm{v} / \mathrm{v}), \mu=0.1 \mathrm{M}(\mathrm{KCl})$ in the presence of one equivalent of $\mathrm{Tb}^{\mathrm{III}}$, at $T=20.0 \pm 0.2^{\circ} \mathrm{C}$ at various $\mathrm{pH}$; curve $\mathrm{a}, \mathrm{b}$, and $\mathrm{c}: \mathrm{pH}=1.92,9.22$, and 12.0 ; the inset shows the absorbance variation at $240 \mathrm{~nm}$

$\mathrm{Tb}^{3+}+\mathrm{H}^{+}+\mathrm{L}^{5-} \stackrel{\beta_{111}}{=}[\mathrm{TbHL}]^{-}$

$\mathrm{Tb}^{3+}+2 \mathrm{H}^{+}+\mathrm{L}^{5-} \stackrel{\beta_{121}}{=}\left[\mathrm{TbH}_{2} \mathrm{~L}\right]$

The calculated distribution curves from these stability constants are presented in Figure 6. In the $\mathrm{pH}$ range $3.5-7.5$, the neutral species $\left[\mathrm{Tb}\left(\mathrm{H}_{2} \mathrm{~L}\right)\right]$ is clearly dominant,

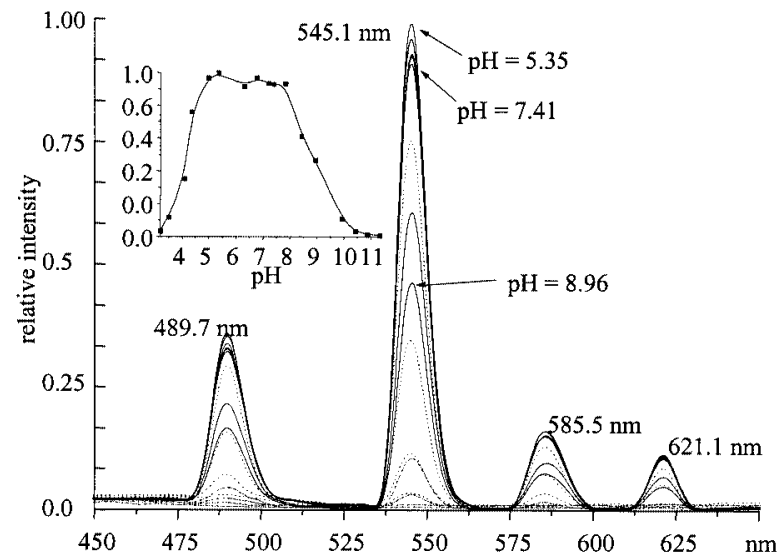

Figure 5. Emission spectra of $\mathrm{H}_{7} \mathrm{~L}^{2+} 2 \cdot 10^{-5} \mathrm{M}$ in $\mathrm{H}_{2} \mathrm{O} / \mathrm{CH}_{3} \mathrm{OH}$ $(98: 2 \mathrm{v} / \mathrm{v}), \mu=0.1 \mathrm{M}(\mathrm{KCl})$ in the presence of one equivalent of $\mathrm{Tb}^{\mathrm{III}}$, at $T=20.0 \pm 0.2^{\circ} \mathrm{C}$ as a function of $\mathrm{pH}$; inset: phosphorescence intensity at $545 \mathrm{~nm}$ vs. $\mathrm{pH}$

Table 2. Absorption maxima of the ligand species at $T=20^{\circ} \mathrm{C}$

\begin{tabular}{llllll}
\hline Species & $\begin{array}{l}\lambda_{\max } \\
(\mathrm{nm})^{[\mathrm{a}]}\end{array}$ & $\begin{array}{l}\varepsilon_{\max } \\
\left(\mathrm{M}^{-1} \cdot \mathrm{cm}^{-1}\right)^{[\mathrm{b}]}\end{array}$ & Species & $\begin{array}{l}\lambda_{\max } \\
(\mathrm{nm})^{[\mathrm{a}]}\end{array}$ & $\begin{array}{l}\varepsilon_{\max } \\
\left(\mathrm{M}^{-1} \cdot \mathrm{cm}^{-1}\right)^{[\mathrm{b}]}\end{array}$ \\
\hline$[\mathrm{L}]^{5-}$ & $268 \mathrm{sh}$ & 3300 & {$\left[\mathrm{H}_{5} \mathrm{~L}\right]$} & 230 & 33800 \\
& & & 278 & 7200 \\
{$\left[\mathrm{HL}^{4-}\right.$} & $268 \mathrm{sh}$ & 3600 & {$\left[\mathrm{H}_{7} \mathrm{~L}\right]^{2+}$} & 277 & 6700 \\
{$\left[\mathrm{H}_{2} \mathrm{~L}\right]^{3-}$} & 272 & 4300 & {$[\mathrm{TbHL}]^{-}$} & $272 \mathrm{sh}$ & 3600 \\
{$\left[\mathrm{H}_{3} \mathrm{~L}\right]^{2-}$} & $228 \mathrm{sh}$ & 30000 & {$\left[\mathrm{TbH}_{2} \mathrm{~L}\right]$} & 272 & 3700 \\
{$\left[\mathrm{H}_{4} \mathrm{~L}\right]^{-}$} & 275 & 5600 & & & \\
& 229 & 33900 & & & \\
& 278 & 6600 & & &
\end{tabular}

${ }^{[a]} \pm 2 \mathrm{~nm} .{ }^{[b]} \pm 10 \%$.

which explains the difficulty in solubilising the metal complexes after their isolation as solid-state samples. At lower $\mathrm{pH}$, competition with protons dissociates the complex, while very stable hydroxides are the major species at $\mathrm{pH}$ values higher than 8.5. Altogether, the metal complexes are moderately stable, as shown by the pTb value of $10.0,{ }^{[19]}$ calculated with $[\mathrm{Tb}]_{\mathrm{tot}}=10^{-6} \mathrm{M},\left[\mathrm{H}_{5} \mathrm{~L}\right]_{\mathrm{tot}}=10^{-5} \mathrm{M}$ and $\mathrm{pH}$ 7.4, in comparison with 19.2 for $[\mathrm{Tb}(\mathrm{dtpa})]^{-}{ }^{[20]}$ and with 6.7 for terbium benzoate. This result is a clear indication that the nitrogen atoms of the $\mathrm{H}_{5} \mathrm{~L}$ ligand are most probably nonbonding and remain protonated in the metal complexes, as indicated by the unchanged values of the two highest apparent $\mathrm{p} K_{a}$ values upon addition of $\mathrm{Ln}^{\mathrm{III}}$ ions.

\section{Photophysical Properties of the Ligand and the $\left[\mathrm{LnH}_{2} \mathrm{~L}\right]$ Complexes}

In water, the ligand displays two main adsorption bands around 46080 (shoulder at $42370 \mathrm{~cm}^{-1}$ ) and $39370 \mathrm{~cm}^{-1}$. The high-energy band is slightly blue-shifted (ca. 400-500 $\mathrm{cm}^{-1}$ ) in the $\mathrm{Ln}^{\mathrm{III}}$ complexes. The photophysical properties of the ligand and of its 1:1 complexes with $\mathrm{La}, \mathrm{Lu}, \mathrm{Eu}$ and $\mathrm{Tb}$ in water $(\mathrm{pH}$ 5.3) and in frozen glycerol/water mixtures are summarized in Table 3. UV excitation in the $\pi \rightarrow \pi^{*}$ and $n \rightarrow \pi^{*}$ absorption bands of the ligand results in a 


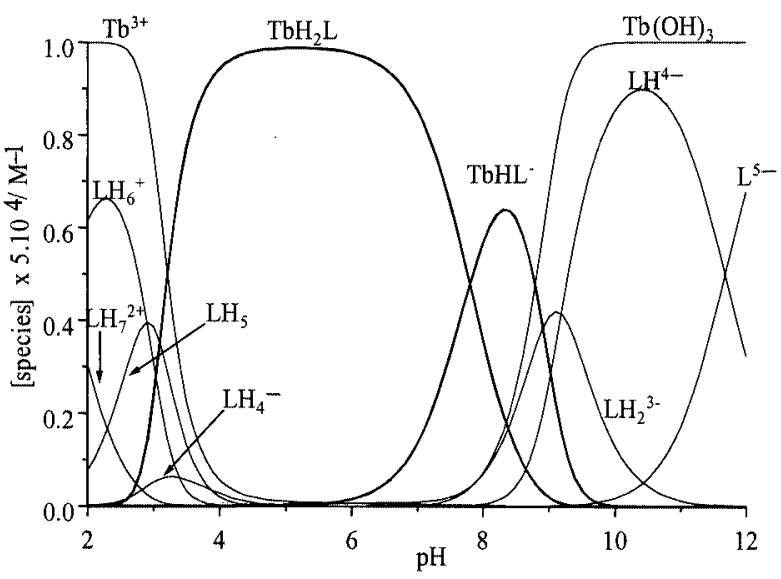

Figure 6. Corresponding formation curves of proton and terbium complexes, computed from the stability constants given in the text; $[\mathrm{L}]_{\mathrm{tot}}=\left[\mathrm{Tb}^{\mathrm{III}}\right]_{\mathrm{tot}}=2.0 \cdot 10^{-5} \mathrm{M} ; \lambda_{\mathrm{exc}}=274 \mathrm{~nm} ; T=20^{\circ} \mathrm{C}$

ligand-centred emission displaying two overlapping bands assigned to emission from the ${ }^{1} \pi \pi^{*}\left(33110 \mathrm{~cm}^{-1}\right)$ and ${ }^{3} \pi \pi^{*}$ states (Figure 7). The absolute fluorescence quantum yield of the fully deprotonated ligand $\left(\mathrm{L}^{5-}\right)$ is small at $0.3 \%$, a value that increases slightly for the $\left[\mathrm{Ln}\left(\mathrm{H}_{2} \mathrm{~L}\right)\right]$ complexes: 0.4 and $0.5 \%$ for $\mathrm{La}$ and $\mathrm{Lu}$, respectively, at $\mathrm{pH}$ 5.3. At $77 \mathrm{~K}$, the ${ }^{3} \pi \pi^{*}$ state emission is structured with a vibrational progression of $1350 \pm 30 \mathrm{~cm}^{-1}$, corresponding to a ring breathing mode and its 0 -phonon transition is located at $26520 \mathrm{~cm}^{-1}$. The gap between the ${ }^{3} \pi \pi^{*}$ and ${ }^{1} \pi \pi^{*}$ states (ca. $6320 \mathrm{~cm}^{-1}$ ) is favourable for a relatively efficient intersystem crossing process. ${ }^{[5]}$ The emission spectra of the ligand and its complexes at room temperature are consistent with this finding, since they display emission from both the singlet and triplet states, although very weakly for $\mathrm{Eu}$ and $\mathrm{Tb}$. The ${ }^{3} \pi \pi^{*}$ lifetime amounts to $1.88 \mathrm{~s}$, a value close to that obtained for benzoic acid $(\tau=2 \mathrm{~s}) \cdot{ }^{[21]}$ As would be expected from the relatively high energy of the ${ }^{3} \pi \pi^{*} 0$ phonon component, both the $\mathrm{Eu}^{\mathrm{III}}$ ions, with $\Delta E\left({ }^{3} \pi \pi^{*}-\right.$ $\left.{ }^{5} \mathrm{D}_{0}\right) \approx 9700 \mathrm{~cm}^{-1}$, and the $\mathrm{Tb}^{\mathrm{III}}$ ions, with $\Delta E\left({ }^{3} \pi \pi^{*}-\right.$ $\left.{ }^{5} \mathrm{D}_{4}\right) \approx 6500 \mathrm{~cm}^{-1}$, are reasonably well sensitised (Figure 7). This is in agreement with what has been observed for $\mathrm{Tb}^{\mathrm{III}}$ poly(aminocarboxylates), for which the best antenna effect was observed for ${ }^{3} \pi \pi^{*}$ states around $26000 \mathrm{~cm}^{-1}$. [22]

The high-resolution excitation spectrum of a solid-state sample of $\left[\mathrm{EuH}_{2} \mathrm{~L}\right]$ in the ${ }^{5} \mathrm{D}_{0} \leftarrow{ }^{7} \mathrm{~F}_{0}$ spectral range, obtained

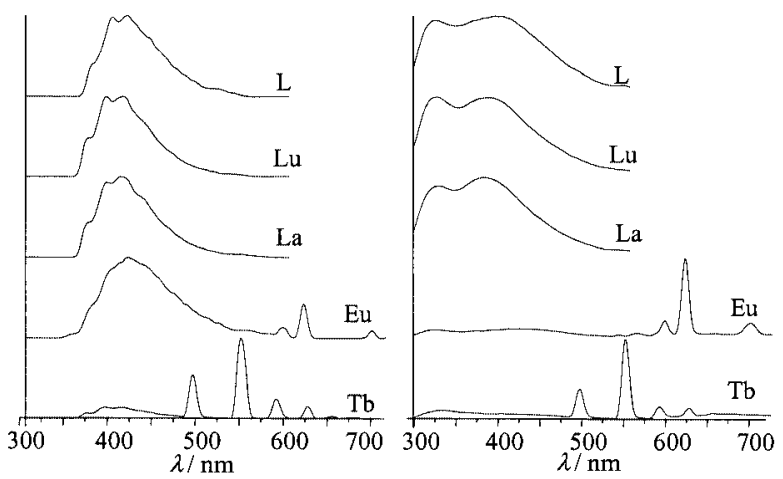

Figure 7. Emission spectra of the $\left[\mathrm{LnH}_{2} \mathrm{~L}\right]$ complexes $(\mathrm{Ln}=\mathrm{La}$, $\mathrm{Eu}, \mathrm{Tb}, \mathrm{Lu}), \mathrm{pH}=5.3$; (left) phosphorescence spectra in solutions of glycerol/water, 10:90\% at $77 \mathrm{~K}$; (right) fluorescence spectra at $295 \mathrm{~K}$ in water

by analysis of the maximum on the ${ }^{5} \mathrm{D}_{0} \rightarrow{ }^{7} \mathrm{~F}_{2}$ transition at $10 \mathrm{~K}$, displays a single broad and symmetrical peak at $17246 \mathrm{~cm}^{-1}$ with a full width at half height (fwhh) of 26.9 $\mathrm{cm}^{-1}$, which is consistent with the presence of a single site for the $\mathrm{Eu}^{\mathrm{III}}$ ion.

The metal-centred luminescence of diluted aqueous solutions is $\mathrm{pH}$ dependent, due to the distribution of the various species present in solution. The $\mathrm{Tb}$ complex displays emission over a large $\mathrm{pH}$ range, from $\mathrm{pH} 3.5$ to 10.5 (Figure 4), with maximum intensity occurring in the $\mathrm{pH}$ range $5-8$, in which $\left[\mathrm{TbH}_{2} \mathrm{~L}\right]$ is the major species in solution. The average numbers of water molecules bound to the metal ions were determined from the experimental lifetimes at room temperature for solutions of $\left[\mathrm{LnH}_{2} \mathrm{~L}\right](\mathrm{Ln}=\mathrm{Eu}, \mathrm{Tb})$ in $\mathrm{H}_{2} \mathrm{O}(\mathrm{pH}$ 5.3) and $\mathrm{D}_{2} \mathrm{O}\left(\mathrm{pD}\right.$ 5.7) ${ }^{[23,24]}$ For the Eu complex, the measured lifetimes $\left(\tau=1.41 \pm 0.04 \mathrm{~ms}\right.$ in $\mathrm{D}_{2} \mathrm{O}$ and $0.20 \pm 0.01$ $\mathrm{ms}$ in $\mathrm{H}_{2} \mathrm{O}$ ) give $q=4.8 \pm 0.5$, while $q=4.5 \pm 0.5$ is obtained for the Tb podate $\left(\tau=1.47 \pm 0.01 \mathrm{~ms}\right.$ in $\mathrm{D}_{2} \mathrm{O}$ and $0.61 \pm 0.01 \mathrm{~ms}$ in $\mathrm{H}_{2} \mathrm{O}$ ). The presence of at least eight $\mathrm{OH}$ oscillators in the inner coordination sphere is consistent with the reasoning, based on the stability constants, that at least four benzoate units are coordinated to the metal ions (in a monodentate fashion), but the nitrogen atoms are not. The large number of water molecules in the first coordination sphere explains the inability of the ligand to sensitise the luminescence of the Dy ${ }^{\mathrm{III}}, \mathrm{Er}^{\mathrm{III}}$ and $\mathrm{Tm}^{\mathrm{III}}$ ions. Despite this, the quantum yields of metal-centred luminescence in

Table 3. Ligand-centred absorption and emission properties of the ligand $(\mathrm{pH} 12)$ and $\left[\mathrm{LnH}_{2} \mathrm{~L}\right]$ podates at $\mathrm{pH} 5.3$

\begin{tabular}{llllll}
\hline Compound & $E\left(\mathrm{~cm}^{-1}\right)^{[\mathrm{a}]}$ & $\begin{array}{l}E\left(\mathrm{~cm}^{-1}\right)^{[\mathrm{a}]} \\
{ }^{1} \pi \pi^{*[\mathrm{c}]}\end{array}$ & ${ }^{3} \pi \pi^{*[\mathrm{c}]}$ & ${ }^{3} \pi \pi^{*[\mathrm{~b}]}$ & $\tau\left({ }^{3} \pi \pi^{*}\right)(\mathrm{ms})^{[\mathrm{b}]}$ \\
\hline$\left[\mathrm{L}^{5-}\right.$ & $46080,42370 \mathrm{sh}, 39370$ & 33110 & 25706 & $26790,25360,23980$ & $1879 \pm 26$ \\
{$\left[\mathrm{LuH}_{2} \mathrm{~L}\right]$} & $46510,42370 \mathrm{sh}, 39275$ & 33005 & 26140 & $26920,25540,24240,22910,21530$ & $789 \pm 12$ \\
{$\left[\mathrm{LaH}_{2} \mathrm{~L}\right]$} & $46590,42370 \mathrm{sh}, 39525$ & 33445 & 26040 & $26880,25510,24210,22940,21600$ & $809 \pm 6$ \\
{$\left[\mathrm{EuH}_{2} \mathrm{~L}\right]$} & $46619,42370 \mathrm{sh}, 36490$ & 33655 & 25445 & $26920,25610,24230$ & $1363 \pm 14$ \\
{$\left[\mathrm{TbH}_{2} \mathrm{~L}\right]$} & $46619,42370 \mathrm{sh}, 36490$ & 33700 & 25640 & $26920,25610,24270$ & $456 \pm 12$ \\
\hline
\end{tabular}

[a] The most intense component is italicised. ${ }^{[\mathrm{b}]}$ Luminescence data and lifetimes for frozen solutions in glycerol/water $10: 90 \%(77 \mathrm{~K})$. ${ }^{[c]}$ Electronic spectroscopic data at $295 \mathrm{~K}$ in water; energies are given for the maximum of the band envelope (sh: shoulder). 
water at pH 5.3 remain sizeable, at 1.5 and $10.3 \%$ for the $\mathrm{Eu}$ and $\mathrm{Tb}$ podates, respectively (Table 4). This points to fairly efficient energy transfer from the ligand to the $\mathrm{Tb}\left({ }^{5} \mathrm{D}_{4}\right)$ level. It is noteworthy that the quantum yield of $\left[\mathrm{Tb}\left(\mathrm{H}_{2} \mathrm{~L}\right)\right]$ increases significantly upon addition of HMPA, which is know to be a good complexation agent for $\mathrm{Ln}^{\mathrm{III}}$ ions and which removes the water from the inner coordination sphere ( 2 eqs: $+45 \%, 4,10,100$ and 500 eqs: $+105 \%$ ). Moreover, a graph of the quantum yield of $\left[\mathrm{Tb}\left(\mathrm{H}_{2} \mathrm{~L}\right)\right]$ vs. $\mathrm{pH}$ (Figure S2, Supporting Information) reflects the distribution curve of this species reasonably well.

\section{Conclusion}

The solution studies described in this paper show that podand $\mathrm{H}_{5} \mathrm{~L}$ gives stable $\mathrm{Ln}^{\mathrm{III}}$ complexes in water that are resistant toward hydrolysis and show interesting photophysical properties. Thermodynamically stable $1: 1$ neutral podates $\left[\mathrm{Ln}\left(\mathrm{H}_{2} \mathrm{~L}\right)\right]$ form in the $\mathrm{pH}$ range 3.7-8. No nitrogen atom is involved in the binding, as a result of the protonation of the amine functions, preventing the wrapping of the ligand around the metal ion. The emission lifetimes of the $\mathrm{Eu}^{\mathrm{III}}$ and $\mathrm{Tb}^{\mathrm{III}}$ complexes recorded in $\mathrm{D}_{2} \mathrm{O}$ and $\mathrm{H}_{2} \mathrm{O}$ point to four water molecules completing the coordination sphere of the metal ions. The luminescence study shows that the ligand exhibits a good antenna effect with respect to the $\mathrm{Tb}^{\mathrm{III}}$ ion, due to efficient intersystem crossing $\left({ }^{1} \pi \pi^{*}\right.$ - to$\left.{ }^{3} \pi \pi^{*}\right)$ and ligand-to-metal energy transfer. Despite the large number of coordinated water molecules, the quantum yields of the metal-centred luminescence in the $\mathrm{Tb}^{\mathrm{III}}$ (and $\mathrm{Eu}^{\mathrm{III}}$ ) complexes are encouraging and demonstrate that benzoate is a potentially interesting moiety for attachment onto a flexible receptor for $\mathrm{Ln}^{\mathrm{III}}$ ions.

\section{Experimental Section}

Starting Materials and General Procedures: Analytical grade solvents and chemicals (Fluka AG) were used without further purification, except for acetonitrile, which was distilled from $\mathrm{CaH}_{2}$. Solutions were prepared just before use with freshly boiled, doubly distilled water saturated with $\mathrm{N}_{2}$. Stock solutions of $\mathrm{LnX}_{3} \cdot n \mathrm{H}_{2} \mathrm{O}(\mathrm{X}=$ $\left.\mathrm{ClO}_{4}, \mathrm{CF}_{3} \mathrm{SO}_{3}\right)$ were prepared from lanthanide oxides $(99.99 \%$, Rhône Poulenc) and the corresponding acid. They were systematically acidified with $\mathrm{HCl}$ to a $\mathrm{pH}$ of about 4 before titration to avoid hydroxide precipitation. The concentrations were determined by complexometric titrations with a standardized $\mathrm{Na}_{2} \mathrm{H}_{2}$ EDTA solution in urotropine-buffered medium and with xylenol orange as indicator. ${ }^{[25]}$ Elemental analyses were performed by Dr. Eder, Microchemical Laboratory, University of Geneva.

1-D and 2-D NMR spectroscopic data were collected on Bruker DPX 400 or AM 360 spectrometers. ${ }^{1} \mathrm{H}$ NMR and ${ }^{13} \mathrm{C}$ NMR spectra were recorded in $\mathrm{CDCl}_{3}, \mathrm{D}_{2} \mathrm{O}$ or $\mathrm{CH}_{3} \mathrm{OD}$ and their assignment was based on ${ }^{1} \mathrm{H}$ coupling and 2-D ${ }^{1} \mathrm{H}^{-13} \mathrm{C}$ correlation spectra. The mass spectra were recorded in electrospray ionisation mode on a Finnigan quadrupole mass spectrometer $\left(T_{\text {matrix }}=240{ }^{\circ} \mathrm{C}\right)$. The instrument was calibrated with a horse myoglobin standard. The analyses were conducted in positive mode. The ion spray voltage was $4.6 \mathrm{kV}$. Assignment of the species was based on the isotopic distribution of the peaks. Electronic UV/Vis spectra were recorded on a Perkin-Elmer Lambda 900 spectrometer. Infra-red spectra were measured on a FT-IR Mattson Alpha Centauri spectrometer (4000-400 $\mathrm{cm}^{-1}, \mathrm{KBr}$ pellets).

Syntheses (see Scheme 1). Methyl 2-(Bromomethyl)benzoate (1): This compound was synthesized by a known procedure. ${ }^{[26]}$

1,4,7-Heptanetriamine- $N, N, N^{\prime}, N^{\prime}, N^{\prime \prime}$-pentakis(methyl 2-methylbenzoate) (2): Potassium carbonate $(10.04 \mathrm{~g}, 72.7 \mathrm{mmol})$ was added under nitrogen atmosphere to a solution of diethylenetriamine $(500 \mathrm{mg}, 4.9 \mathrm{mmol})$ in freshly distilled acetonitrile $(100 \mathrm{~mL})$. The resulting mixture was heated at reflux for $30 \mathrm{~min}$, and a solution of $1(6.08 \mathrm{~g}, 26.7 \mathrm{mmol})$ in dry acetonitrile $(50 \mathrm{~mL})$ was added over $2 \mathrm{~h}$. The mixture was stirred and heated at reflux for an additional $12 \mathrm{~h}$ and filtered while hot. The solvents were then evaporated to give a black oil, which was dissolved in dichloromethane, washed with brine and dried with $\mathrm{Mg}_{2} \mathrm{SO}_{4}$, and the solvents were evaporated to dryness. The residue was purified by column chromatography (silica gel; $2 \% \mathrm{MeOH}$ in $\mathrm{CH}_{2} \mathrm{Cl}_{2}$ ). Yield: $1.76 \mathrm{~g}(43 \%$ ), orange foam. IR $(\mathrm{KBr}): \tilde{v}=1711(\mathrm{C}=\mathrm{O}), 1452,1384 \mathrm{~cm}^{-1} .{ }^{1} \mathrm{H}$ NMR $\left(300 \mathrm{MHz}, \mathrm{CDCl}_{3}, 25^{\circ} \mathrm{C}\right): \delta=2.46\left(\mathrm{~m}, 8 \mathrm{H}, \mathrm{CH}_{2}\right), 3.72(\mathrm{~s}, 8 \mathrm{H}$, $\left.\mathrm{CH}_{2}\right), 3.76\left(\mathrm{~s}, 2 \mathrm{H}, \mathrm{CH}_{2}\right), 3.82\left(\mathrm{~s}, 12 \mathrm{H}, \mathrm{CH}_{3}\right), 3.86\left(\mathrm{~s}, 3 \mathrm{H}, \mathrm{CH}_{3}\right)$, $7.21(\mathrm{~m}, 5 \mathrm{H}, \mathrm{ArH}), 7.27\left(\mathrm{dt},{ }^{1} J=7.5,{ }^{2} J=1.3 \mathrm{~Hz}, 1 \mathrm{H}, \mathrm{ArH}\right)$, $7.34\left(\mathrm{dt},{ }^{1} J=7.8,{ }^{2} J=1.3 \mathrm{~Hz}, 4 \mathrm{H}, \mathrm{ArH}\right), 7.41(\mathrm{~d}, J=7.5 \mathrm{~Hz}, 1$ $\mathrm{H}, \mathrm{ArH}), 7.58(\mathrm{~d}, J=7.8 \mathrm{~Hz}, 4 \mathrm{H}, \mathrm{ArH}), 7.68\left(\mathrm{dd},{ }^{1} J=7.5,{ }^{2} J=\right.$ $1.3 \mathrm{~Hz}, 1 \mathrm{H}, \mathrm{ArH}), 7.74\left(\mathrm{dd},{ }^{1} J=7.8,{ }^{2} J=1.3 \mathrm{~Hz}, 4 \mathrm{H}, \mathrm{ArH}\right)$ ppm. ${ }^{13} \mathrm{C} \mathrm{NMR}\left(\mathrm{CDCl}_{3}\right): \delta=51.7,51.8\left(\mathrm{CH}_{3}\right), 52.5,52.6,57.0$, $57.6\left(\mathrm{CH}_{2}\right), 126.3,129.3,129.7,129.9(\mathrm{CH}), 130.1,130.4(\mathrm{Cq})$, 131.3, $131.6(\mathrm{CH}), 141.4(\mathrm{Cq}), 168.2,168.4(\mathrm{C}=\mathrm{O})$ ppm. ESI$\mathrm{MS}\left(\mathrm{CH}_{3} \mathrm{CN}, \mathrm{H}_{2} \mathrm{O}, \mathrm{CH}_{3} \mathrm{CO}_{2} \mathrm{H}\right): m / z=844.3$ (calcd. 844.3) $[\mathrm{M}+$ $\mathrm{H}]^{+}, 422.8$ (calcd. 422.7) $[\mathrm{M}+2 \mathrm{H}]^{2+} \cdot \mathrm{C}_{49} \mathrm{H}_{53} \mathrm{~N}_{3} \mathrm{O}_{10}$ (843.97): calcd. C 69.73, H 6.33, N 4.98; found C 69.72, H 6.31, N 4.96.

1,4,7-Heptanetriamine- $N, N, N^{\prime}, N^{\prime}, N^{\prime \prime}$-pentakis(2-methylbenzoic acid) $\left(\mathbf{H}_{\mathbf{5}} \mathbf{L}\right)$ : Compound $\mathbf{2}(500 \mathrm{mg}, 0.59 \mathrm{mmol})$ was dissolved in a solution of methanol $(200 \mathrm{~mL})$ and $\mathrm{KOH}$ in water $(1 \mathrm{M}, 15 \mathrm{~mL})$. The resulting mixture was heated at reflux for $4 \mathrm{~h}$, and the solvents were evaporated. The residue was dissolved in water $(400 \mathrm{~mL})$, cooled to $0{ }^{\circ} \mathrm{C}$ and acidified to $\mathrm{pH} 2$ with aqueous $\mathrm{HCl}$. The yellow precipitate was collected, washed with water and then diethyl ether, and dried. Yield: $417 \mathrm{mg}$ (91\%), yellow solid. IR (KBr): $\tilde{v}=3426$ br $(\mathrm{OH}), 2606$ br $(\mathrm{OH}), 1700(\mathrm{C}=\mathrm{O}), 1590,1552,1451,1381,1295$, $1145,1085,752 \mathrm{~cm}^{-1} .{ }^{1} \mathrm{H}$ NMR $\left(300 \mathrm{MHz}, \mathrm{D}_{2} \mathrm{O}, 20{ }^{\circ} \mathrm{C}\right): \delta=2.8$ $\left(\mathrm{m}, 4 \mathrm{H}, \mathrm{CH}_{2}\right), 3.3\left(\mathrm{~m}, 4 \mathrm{H}, \mathrm{CH}_{2}\right), 3.63\left(\mathrm{~s}, 2 \mathrm{H}, \mathrm{CH}_{2}\right), 4.44(\mathrm{~s}, 8 \mathrm{H}$, $\left.\mathrm{CH}_{2}\right), 7.2(\mathrm{~m}, 1 \mathrm{H}, \mathrm{ArH}), 7.3-7.4(\mathrm{~m}, 14 \mathrm{H}, \mathrm{ArH}), 7.74(\mathrm{~m}, 1 \mathrm{H}$, $\mathrm{ArH}), 7.93$ (m, $4 \mathrm{H}, \mathrm{ArH}) \mathrm{ppm} .{ }^{13} \mathrm{C}$ NMR $\left(\mathrm{D}_{2} \mathrm{O}, 20{ }^{\circ} \mathrm{C}\right): \delta=51.1$, 55.4, 56.7, 57.9, $58.1\left(\mathrm{CH}_{2}\right), 127.2,129.6,130.6,130.8(\mathrm{CH}), 131.4$, 131.6 (quat. C), 133.1, $134.4(\mathrm{CH}), 137.5$ (quat. C), $170.7(\mathrm{C}=\mathrm{O})$ ppm. ESI-MS $\left(\mathrm{CH}_{3} \mathrm{CN}, \mathrm{H}_{2} \mathrm{O}, \mathrm{CH}_{3} \mathrm{CO}_{2} \mathrm{H}\right): \mathrm{m} / z=774.4$ (calcd. 774.3) $[\mathrm{M}+\mathrm{H}]^{+}, 387.8$ (calcd. 387.7) $[\mathrm{M}+2 \mathrm{H}]^{2+} \cdot \mathrm{H}_{5} \mathrm{~L} \cdot \mathrm{H}_{2} \mathrm{O}$ $\mathrm{C}_{44} \mathrm{H}_{45} \mathrm{~N}_{3} \mathrm{O}_{11}$ (791.85): calcd. C 66.74, H 5.73, N 5.31; found $\mathrm{C}$ 66.72, H 5.60, N 5.20.

Preparation of $\left[\mathrm{Ln}\left(\mathrm{H}_{2} \mathrm{~L}\right)\right] \cdot \boldsymbol{n} \mathrm{H}_{2} \mathrm{O}$ Complexes $(\mathrm{Ln}=\mathrm{La}, \mathrm{Eu}, \mathrm{Tb}, \mathrm{Lu})$ : Freshly titrated $\mathrm{LnClO}_{4} \cdot n \mathrm{H}_{2} \mathrm{O}$ solutions $\left(10^{-3} \mathrm{M}, 0.039 \mathrm{mmol}\right)$ were added over $4 \mathrm{~h}$, at room temperature, to an aqueous solution of $\mathrm{H}_{5} \mathrm{~L}\left(40 \mathrm{~mL}, 0.039 \mathrm{mmol}, 10^{-3} \mathrm{M}, \mathrm{pH}=5.3\right.$, adjusted with $\mathrm{HCl}$ ). The mixture was stirred for an additional $2 \mathrm{~h}$ and the resulting white precipitate was filtered, washed successively with water (several times) and diethyl ether, and further dried for 3 days at $65^{\circ} \mathrm{C}$ and 0.01 Torr. These complexes being very hygroscopic, variable numbers of water molecules were found when performing microanalyses.

$\left[\mathrm{La}\left(\mathrm{H}_{2} \mathrm{~L}\right)\right] \cdot 5 \mathrm{H}_{2} \mathrm{O}(75 \%):$ IR $(\mathrm{KBr}): \tilde{v}=3422$ br $(\mathrm{OH}), 1554$ and $1399\left(v_{\text {as }}, v_{\mathrm{s}}\right.$ COO), 1606, 1498, 1449, 1294, 1203, 1151, 1120, 1089 , 
$753 \mathrm{~cm}^{-1} \cdot \mathrm{C}_{44} \mathrm{H}_{50} \mathrm{LaN}_{3} \mathrm{O}_{15}$ (999.80): calcd. C 52.86, H 5.04, N 4.20; found $\mathrm{C} 52.27, \mathrm{H} 4.50, \mathrm{~N} 4.27$.

$\left[\mathrm{Eu}\left(\mathrm{H}_{2} \mathrm{~L}\right)\right] \cdot 3 \mathrm{H}_{2} \mathrm{O}(89 \%)$ : IR $(\mathrm{KBr}): \tilde{v}=3413$ br $(\mathrm{OH}), 1556$ and 1403 ( $v_{\mathrm{as}}, v_{\mathrm{s}}$ COO), 1607, 1490, 1449, 1294, 1202, 1150, 1120, 1094 , $752 \mathrm{~cm}^{-1}$. ESI-MS: a stoichiometric mixture of $\mathrm{Eu}\left(\mathrm{ClO}_{4}\right)_{3} \cdot x \mathrm{H}_{2} \mathrm{O}$ $(x=4.2)$ and $\mathrm{H}_{5} \mathrm{~L} 10^{-4} \mathrm{M}$ in pure methanol gave $\left[\mathrm{EuH}_{3} \mathrm{~L}\right]^{+} \mathrm{m} / z=$ 923.4 (calcd. 923.4). $\mathrm{C}_{44} \mathrm{H}_{46} \mathrm{EuN}_{3} \mathrm{O}_{13}$ (976.81): calcd. C 54.10, $\mathrm{H}$ 4.75, N 4.30; found C 53.65, H 4.59, N 4.30.

$\left[\mathrm{Tb}\left(\mathrm{H}_{2} \mathrm{~L}\right)\right] \cdot 7 \mathrm{H}_{2} \mathrm{O}(84 \%)$ : IR $(\mathrm{KBr}): \tilde{v}=3416$ br $(\mathrm{OH}), 1556$ and $1407\left(v_{\mathrm{a}}, v_{\mathrm{s}} \mathrm{COO}\right), 1608,1491,1450,1295,1203,1151,1120,1087$, $752 \mathrm{~cm}^{-1} \cdot \mathrm{C}_{44} \mathrm{H}_{54} \mathrm{~N}_{3} \mathrm{O}_{17} \mathrm{~Tb}$ (1055.83): calcd. C 50.05, H 5.15, N 3.98; found $\mathrm{C} 49.16, \mathrm{H} 4.78, \mathrm{~N} 3.72$. Complexometry: calcd. Tb 15.05; found $\mathrm{Tb} 15.28 \pm 0.28$.

$\left[\mathrm{Lu}\left(\mathrm{H}_{2} \mathrm{~L}\right)\right] \cdot 4 \mathrm{H}_{2} \mathrm{O}(92 \%):$ IR $(\mathrm{KBr}): \tilde{v}=3417$ br $(\mathrm{OH}), 1561$ and $1410\left(v_{\mathrm{as}}, v_{\mathrm{s}} \mathrm{COO}\right), 1608,1491,1450,1294,1203,1152,1120,1088$, $752 \mathrm{~cm}^{-1} . \mathrm{C}_{44} \mathrm{H}_{48} \mathrm{~N}_{3} \mathrm{O}_{14} \mathrm{Lu}$ (1017.84): calcd. C 51.92, H 4.75, N 4.13; found C 51.98, H 4.41, N 4.14.

Physical Measurements. Potentiometric Titrations: $\mathrm{H}_{7} \mathrm{~L}^{2+}$ was titrated with a $5.1 \mathrm{~mL}$ sample $\left(\left[\mathrm{H}_{7} \mathrm{~L}^{2+}\right]_{\text {tot }}=3.7 \cdot 10^{-3} \mathrm{M}\right.$, solvent: $\left.\mathrm{H}_{2} \mathrm{O} / \mathrm{CH}_{3} \mathrm{OH} 98: 2 \mathrm{v} / \mathrm{v}\right)$ in a thermostatted $\left(20.0 \pm 0.1{ }^{\circ} \mathrm{C}\right)$ glassjacketed vessel under an $\mathrm{Ar}$ atmosphere. The ionic strength was fixed with $\mathrm{KCl}(\mu=0.1 \mathrm{M})$. The solution was acidified to a $\mathrm{pH}$ of about $1.8(\mathrm{HCl}) 30 \mathrm{~min}$ before titration. Titrations were carried out with an automatic Metrohm Titrino 736 GP potentiometer linked to an IBM PS/2 computer (resolution $0.1 \mathrm{mV}$, accuracy $0.2 \mathrm{mV}$ ) and by use of constant volume addition $(0.05 \mathrm{~mL})$. An automatic burette (Metrohm 6.3013.210, $10 \mathrm{~mL}$, accuracy $0.03 \mathrm{~mL}$ ) was used, together with a Metrohm 6.0238.000 glass electrode. The standard base solution $(\mathrm{KOH}=0.050 \mathrm{M}, \mu=0.1 \mathrm{M}, \mathrm{KCl})$ was added inside the solution through a capillary tip attached to the automatic burette. The data ( 200 points, drift $<1 \mathrm{mV} / \mathrm{min}$ ) were mathematically treated by use of the program SUPERQUAD ${ }^{[27]}$ with a Marquardt algorithm while the distribution of species was calculated with the program Haltafall. ${ }^{[28]}$ Calibration of the $\mathrm{pH}$ meter and the electrode system was performed prior to each measurement with a standardized $\mathrm{HCl}$ solution $(\mu=0.1 \mathrm{M}, \mathrm{KCl})$ at $20.0^{\circ} \mathrm{C}: 10 \mathrm{~mL}$ of the latter were titrated with a standardized $0.1 \mathrm{M} \mathrm{KOH}$ solution at a ionic strength of 0.1 , and the electrode potential readings were converted to $\mathrm{pH}$. The ion product of solvent $\left(\mathrm{p} K_{\mathrm{w}}=13.91\right)$ and electrode potential were refined by use of the program Scientist ${ }^{\circledR}$ by Micromath ${ }^{\circledR}$ (Version 2.0).

Spectrophotometric Titrations: Electronic spectra were recorded with a Perkin-Elmer Lamdba 900 spectrophotometer at $20{ }^{\circ} \mathrm{C}$ $\left(210-350 \mathrm{~nm}, 60 \mathrm{~nm} \mathrm{~min}{ }^{-1}\right.$ scan speed, spectral width $\left.2 \mathrm{~nm}\right)$ in 1 $\mathrm{cm}$ Suprasil ${ }^{\circledR}$ quartz cells. Titrations of $10 \mathrm{~mL}$ samples were performed in a thermostatted $\left(20.0 \pm 0.1{ }^{\circ} \mathrm{C}\right)$, glass-jacketed vessel filled with $\mathrm{Ar}$, at $\mu=1 \mathrm{M}(\mathrm{KCl}) ; \mathrm{H}_{7} \mathrm{~L}^{2+}(\mathrm{pH}, 2)$ was titrated with $\mathrm{KOH}(0.1 \mathrm{M}), \mathrm{H}_{5} \mathrm{~L}(\mathrm{pH}, 5.3, \mathrm{HCl})$ with $\mathrm{Ln}\left(\mathrm{ClO}_{4}\right)_{3}\left(\approx 4.0 \cdot 10^{-3} \mathrm{M}\right.$, $\mathrm{Ln}=\mathrm{La}, \mathrm{Eu}, \mathrm{Tb}, \mathrm{Lu})$ at $\mathrm{pH}=5.3$, and $\left[\mathrm{Tb}\left(\mathrm{H}_{2} \mathrm{~L}\right)\right] 2.0 \cdot 10^{-5} \mathrm{M}$ at $\mathrm{pH}_{0} \approx 2$ by $\mathrm{KOH}(0.050 \mathrm{M})$. Aliquots of the titrant were added through a Socorex ${ }^{\circledR}$ micropipette. The $\mathrm{pH}$ values of the titrated solutions were monitored continuously. After a $15 \mathrm{~min}$ delay, $3 \mathrm{~mL}$ of solution was transferred into the quartz cell with a Teflon ${ }^{\circledR}$ syringe. The stability constants were computed by use of the Specfit program. ${ }^{[29]}$ Differences between the measured and the computed absorbances were less than $7 \times 10^{-3}$ absorbance unit at any wavelength and exhibited statistical behaviour.

NMR Titration: A solution of $\mathrm{H}_{5} \mathrm{~L}\left(11.6 \mathrm{mg}, 7.3 \cdot 10^{-3} \mathrm{M}\right)$ was prepared in $2 \mathrm{~mL}$ of a $\mathrm{D}_{2} \mathrm{O} / \mathrm{CD}_{3} \mathrm{OD}(95: 5$, v/v) mixture, by addition of a concentrated $\mathrm{KOD} / \mathrm{D}_{2} \mathrm{O}$ aliquot $\left(\mathrm{pD}_{0} \approx 12\right)$. Samples with different $\mathrm{pD}$ values were prepared by addition of dilute $\mathrm{D}_{2} \mathrm{SO}_{4} /$ $\mathrm{D}_{2} \mathrm{O}$ (Fluka, puriss). Precipitation of ligand occurred at $\mathrm{pD}$ values lower than 3.2. The $\mathrm{pH}$ values of the solutions were determined with a Metrohm Titrino 736 GP potentiometer equipped with a calibrated Metrohm 6.0234.100 glass electrode in $\mathrm{H}_{2} \mathrm{O}$. Ionic strength was not adjusted. The $\mathrm{pD}$ values were obtained from the equation $\mathrm{pD}=\mathrm{pH}_{\text {measd. }}+0.4 .^{[30]}$

Luminescence Titrations: The solutions $\left\{\left[\mathrm{H}_{5} \mathrm{~L}\right]_{0}=2.0 \cdot 10^{-5} \mathrm{M}\right.$, $\left[\mathrm{Tb}\left(\mathrm{ClO}_{4}\right)_{3}\right]_{0}=2.0 \cdot 10^{-5} \mathrm{M}, 10 \mathrm{~mL}, \mathrm{pH}_{0} \approx 2 ;[\mathrm{KOH}]_{\mathrm{tit}}=0.050 \mathrm{M}$; $\mu=0.1 \mathrm{M}(\mathrm{KCl})\}$ were identical to those used for the spectrophotometric $\mathrm{pH}$-dependent titration described previously. After a $15 \mathrm{~min}$ delay, $3 \mathrm{~mL}$ of solution were transferred into a quartz cell and degassed with Ar for $5 \mathrm{~min}$. Absorbance at the excitation wavelength was measured $(A<0.05)$ and emission $\left(\lambda_{\text {exc }}=285 \mathrm{~nm}\right)$ and excitation spectra were collected.

Luminescence Measurements: Low-resolution luminescence measurements (spectra and lifetimes) were recorded on a Perkin-Elmer LS-50B spectrofluorimeter. Phosphorescence lifetimes $(\tau)$ were measured with the instrument in time-resolved mode, on frozen glycerol/water $(10: 90 \%)$ solutions in a quartz capillary or a $1-\mathrm{cm}$ Suprasil ${ }^{\circledR}$ cell. They are the average of at least three independent measurements, made by monitoring the decay at the maxima of the emission spectra, enforcing a $0.03-0.04 \mathrm{~ms}$ delay. The decays were mono-exponential and were analysed by use of the FLDM program (Perkin-Elmer). Solutions of $\left[\operatorname{Ln}\left(\mathrm{H}_{j} \mathrm{~L}\right)\right]^{(3+j-5)+}$ were prepared in water at $\mathrm{pH}=5.3$, with stock solutions of $\mathrm{H}_{5} \mathrm{~L}\left(2.0 \cdot 10^{-3}\right.$ M) and $\mathrm{Ln}\left(\mathrm{ClO}_{4}\right)_{3} \cdot x \mathrm{H}_{2} \mathrm{O}\left(x \approx 4.5, \mathrm{Ln}=\mathrm{La}, \mathrm{Eu}, \mathrm{Tb}, \mathrm{Lu} ; \approx 4 \cdot 10^{-3}\right.$ M). Quantum yields of $\mathrm{L}^{5-}\left(10^{-5} \mathrm{M}, \mathrm{pH}=12\right)$ and $\left[\mathrm{Ln}\left(\mathrm{H}_{2} \mathrm{~L}\right)\right](\mathrm{Ln}=$ $\mathrm{La}, \mathrm{Eu}, \mathrm{Tb}, \mathrm{Lu}, 10^{-5} \mathrm{M}$ in $\mathrm{H}_{2} \mathrm{O}$ ) were determined in degassed water relative to quinine sulfate in $0.05 \mathrm{M}$ aqueous $\mathrm{H}_{2} \mathrm{SO}_{4}$ (absolute quantum yield: 0.546$)^{[31]}$ and cresol violet (absolute quantum yield: $0.52) ;{ }^{[32]}$ estimated error $\pm 10 \%$. The number of coordinated water molecules $(q)$ for the $\mathrm{Eu}$ and $\mathrm{Tb}$ complexes were calculated from $q=A\left(\tau_{\mathrm{H}}^{-1}-\tau_{\mathrm{D}}^{-1}-k_{\text {corr }}\right)$, where $\tau_{\mathrm{H}}$ and $\tau_{\mathrm{D}}$ are the lifetimes in $\mathrm{H}_{2} \mathrm{O}$ and $\mathrm{D}_{2} \mathrm{O}$ respectively, $A=1.2(\mathrm{Eu})$ and $5.0(\mathrm{~Tb})$, and $k_{\text {corr }}=$ $0.25(\mathrm{Eu})$ and $0.06(\mathrm{~Tb}) \mathrm{ms}^{-1} \cdot{ }^{[24]}$ High-resolution spectra were recorded on a previously described setup. ${ }^{[33]}$

Table 4. Absolute quantum yield of the ligand-centred fluorescence in $[\mathrm{L}]^{5-}(\mathrm{pH}=12)$ and $\left[\mathrm{LnH}_{2} \mathrm{~L}\right](\mathrm{Ln}=\mathrm{La}, \mathrm{Lu})$ and of the metalcentred phosphorescence in $\left[\mathrm{LnH}_{2} \mathrm{~L}\right](\mathrm{Ln}=\mathrm{Eu}, \mathrm{Tb})$ measured in water at $295 \mathrm{~K}$ and $\mathrm{pH}=5.3$ (values in $\mathrm{D}_{2} \mathrm{O}$ are italicised)

\begin{tabular}{llc}
\hline Compound & $\lambda_{\text {exc }}(\mathrm{nm})$ & $\varphi_{\text {abs }}(\%)$ \\
\hline$[\mathrm{L}]^{5-}$ & 268 & 0.3 \\
{$\left[\mathrm{LuH}_{2} \mathrm{~L}\right]$} & 273 & 0.4 \\
{$\left[\mathrm{LaH}_{2} \mathrm{~L}\right]$} & 273 & 0.5 \\
{$\left[\mathrm{EuH}_{2} \mathrm{~L}\right]$} & 270 & $1.5,3.3$ \\
{$\left[\mathrm{TbH}_{2} \mathrm{~L}\right]$} & 270 & $10.3,18.9$ \\
\hline
\end{tabular}

\section{Acknowledgments}

This work is supported through grants from the Swiss National Science Foundation and the Swiss Federal Office for Science and Education (COST Action D18). We thank Frédéric Gumy for his help in recording the high-resolution luminescence data.

[1] The chemistry of contrast agents in medical magnetic resonance imaging, eds A. E. Merbach and E. Tóth, Wiley, London, 2001.

[2] Z. P. Zheng, Chem. Commun. 2001, 2521-2529.

[3] J.-C. G. Bünzli, C. Piguet, Chem. Rev. 2002, 102, 1897-1928. 
[4] L. H. Slooff, A. van Blaaderen, A. Polman, G. A. Hebbink, S. I. Klink, F. C. J. M. Van Veggel, D. N. Reinhoudt, J. W. Hofstraat, J. Appl. Phys. 2002, 91, 3955-3980.

[5] J.-C. G. Bünzli, C. Piguet, in Encylopedia of Materials: Science and Technology (Eds.: K. H. J. Buschow, R. W. Cahn, M. C. Flemings, B. Ilschner, E. J. Kramer, S. Mahajan), Elsevier Science Ltd, Oxford, 2001, 10, Ch. 1. 10. 4, 4465-76.

[6] V. W. W. Yam, K. K. W. Lo, Coord. Chem. Rev. 1999, 184, $157-240$.

[7] G. Mathis, in Rare Earths (Eds.: R. Saez Puche, P. Caro), Editorial Complutense, Madrid, 1998, 285-97.

[8] D. Parker, Coord. Chem. Rev. 2000, 205, 109-130.

[9] D. J. Bornhop, D. S. Hubbard, M. P. Houlne, C. Adair, G. E. Kiefer, B. C. Pence, D. L. Morgan, Anal. Chem. 1999, 71, 2607-2615.

${ }^{[10]}$ G. Zucchi, A.-C. Ferrand, R. Scopelliti, J.-C. G. Bünzli, Inorg. Chem. 2002, 41, 2459-2465.

${ }^{[11]}$ F. M. Ramirez, L. J. Charbonnière, G. Muller, R. Scopelliti, J.C. G. Bünzli, J. Chem. Soc., Dalton Trans. 2001, 3205-3213.

${ }^{[12]}$ C. Piguet, J.-C. G. Bünzli, Chem. Soc. Rev. 1999, 28, 347-358.

${ }^{[13]}$ M. Elhabiri, R. Scopelliti, J.-C. G. Bünzli, C. Piguet, J. Am. Chem. Soc. 1999, 121, 10747-10762.

${ }^{[14]}$ N. Fatin-Rouge, E. Tóth, D. Perret, R. H. Backer, A. E. Merbach, J.-C. G. Bünzli, J. Am. Chem. Soc. 2000, 122, $10810-10820$.

${ }^{[15]}$ J.-C. G. Bünzli, in Rare Earths (Eds.: R. Saez Puche, P. Caro), Editorial Complutense, Madrid, 1998, 223-259.

${ }^{[16]}$ W. Shrott, H. Büchner, U. E. Steiner, J. Inf. Recording 1996, $23,79-84$.

${ }^{[17]}$ M. Bredol, U. Kynast, C. Ronda, Adv. Mat. 1991, 3, 361-367.

[18] J. L. Sudmeier, C. N. Reilley, Anal. Chem. 1964, 36, $1698-1706$.

${ }^{[19]}$ K. N. Raymond, G. Muller, F. Matzanke, Top. Curr. Chem. 1984, 123, 49-102.
[20] J. R. Duffield, F. Marsicano, D. R. Williams, Polyhedron. 1991, $10,1105-1111$.

${ }^{[21]}$ H. J. Maria, S. P. McGlynn, J. Chem. Phys. 1970, 52, 3399-3402.

${ }^{[22]}$ M. Latva, H. Takalo, V. M. Mukkala, C. Matachescu, J.-C. Rodriguez-Ubis, J. Kankare, J. Lumin. 1997, 75, 149-169.

${ }^{[23]}$ J.-C. G. Bünzli, in Lanthanide Probes in Life, Chemical and Earth Sciences. Theory and Practice (Eds.: J.-C. G. Bünzli, G. R. Choppin), Elsevier Science Publ. B. V., Amsterdam, 1989, chapter 7, 219-93.

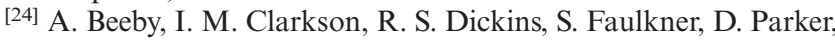
L. Royle, A. S. de Sousa, J. A. G. Williams, M. Woods, J. Chem. Soc., Perkin Trans. 2 1999, 493-504.

${ }^{[25]}$ G. Schwarzenbach, Complexometric Titrations, Chapman \& Hall, London, 1957.

${ }^{[26]}$ D. A. Quagliato, P. M. Andrae, E. M. Matelan, J. Org. Chem. 2000, 65, 5037-5042.

[27] P. Gans, A. Sabatini, A. Vacca, J. Chem. Soc., Dalton Trans. 1985, 1195-1200.

${ }^{[28]}$ N. Ingri, W. Kakolowicz, L. G. Sillen, B. Warnqvist, Talanta 1967, 14, 1261-1286.

${ }^{[29]}$ H. Gampp, M. Maeder, C. J. Meyer, A. D. Zuberbühler, Talanta 1986, 33, 943-951.

${ }^{[30]}$ K. Mikkelsen, S. O. Nielsen, J. Phys. Chem. 1960, 64, 632-637.

[31] S. R. Meech, D. C. Phillips, J. Photochem. 1983, 23, 193-217.

${ }^{[32]}$ D. Magde, J. H. Brannon, T. L. Cremers, J. Olmsted, III, J. Phys. Chem. 1979, 83, 696-699.

${ }^{[33]}$ R. Rodriguez-Cortinas, F. Avecilla, C. Platas-Iglesias, D. Imbert, J.-C. G. Bünzli, A. de Blas, T. Rodriguez-Blas, Inorg. Chem. 2002, 41, 5336-5349.

[34] P. Letkeman, A. E. Martell, Inorg. Chem. 1979, 18, 1284-1289.

Received October 4, 2002

[I02550] 